\title{
GASEOUS RELEASES EVALUATION AND SAFETY PERFORMANCE IMPROVEMENT OF KARTINI RESEARCH REACTOR VENTILATION SYSTEM
}

\author{
Syarip, Edy Triono BS \\ Staff of the Center for Technology of Accelerator and Material Process, BATAN, Yogyakarta. \\ Widyatmaka Susyanta, Hadi Kusuma \\ Staff of the Center for Reactor Technology and Nuclear Safety, BATAN, Serpong. \\ e-mail : ptapb@batan.go.id
}

Received 5 November 2010, received in revised form 29 November 2010, accepted 30 November 2010

\begin{abstract}
GASEOUS RELEASES EVALUATION AND SAFETY PERFORMANCE IMPROVEMENT OF KARTINI RESEARCH REACTOR VENTILATION SYSTEM. The safety performance of Kartini research reactor related to the gaseous releases to the environment has been evaluated. The research covers an evaluation and improvement on the ventilation system and analysis of gas releases dissipating from the reactor building. The method used is calculation of reactor source term and direct measurement of gas release from the reactor stack. The source term analysis showed that the fission product accumulated in the reactor core at the start of operation was $4.838 \times 10^{6} \mathrm{Ci}$, after of 5 hours operation it became $3.614 \times 10^{8} \mathrm{Ci}$, and after 24 hours decay, the fission product became $4.727 \times 10^{6} \mathrm{Ci}$. The $N^{16}$ activity inside the reactor building is $4.1 \times 10^{-10} \mu \mathrm{Ci}^{-\mathrm{cm}^{3}}$ and the $A \mathrm{~A}^{41}$ escaping to the atmosphere is $5.7 \times 10^{-}$ ${ }^{12} \mathrm{mCi} / \mathrm{cm}^{3}$, which is lower than limit value for radiation worker of $2 \times 10^{-6} \mu \mathrm{Ci} / \mathrm{cm}^{3}$. A sample case by using March 2009 data, the value of ground level concentration on variable distance $x=100 \mathrm{~m}$ to $5.000 \mathrm{~m}$, was $9.726 \times 10^{-19}$ $\mathrm{rad} / \mathrm{m}^{3}$, rise up to $6.303 \times 10^{-14} \mathrm{rad} / \mathrm{m}^{3}$ and tends to decrease to $1.598 \times 10^{-15} \mathrm{rad} / \mathrm{m}^{3}$ at distance $5,000 \mathrm{~m}$. Whiles the direct observation on the upper reactor stack show that the radiation exposure is $2.33 \times 10^{-9} \mathrm{rad} / \mathrm{s}$, exit velocity of gas from stack is $8 \mathrm{~m} / \mathrm{s}$, absolute temperature effluent of gas is $26.2{ }^{\circ} \mathrm{C}$, and outlet diameter of stack, $d=1 \mathrm{~m}$ and actual stack height $31.75 \mathrm{~m}$. Based on safety limit criteria from national regulation (BAPAETEN), the values of radiation exposure, ground level concentration combined with atmosphere stability and demography factor was very safe for the actual condition of Kartini reactor site.
\end{abstract}

Keywords: safety performance, Kartini reactor, source term, ventilation system.

\section{INTRODUCTION}

$\mathrm{K}^{\mathrm{a}}$ artini reactor is a TRIGA Mark II type research reactor operated by Center for Accelerator and Material Process Technology (CAMPT) of Indonesian National Nuclear Energy Agency (BATAN). Head of the CAMPT is fully responsible for conducting safe operation and utilization of the research reactor. He shall report to the Head of BATAN and to the Regulatory Body (BAPETEN) in operating and utilizing the research reactor safely. Kartini adopted a ventilation system which was specifically designed for IRT-2000, a Russian reactor. This adoption raises a need of performance validation of the system, which estimates the possibility of radiological consequences to the environment. It was suspected that $\mathrm{Ar}^{\mathrm{r}}$ and $\mathrm{N}^{16}$ gases unexpectedly leaked from the building. It is essential that the leakage of this release is assured by in-situ evaluation and computer calculation.

This research is sponsored by the IAEA through a Technical Cooperation Project granted for the period of 2008 - 2009. This paper is a part of the progress report of the IAEA Technical Cooperation Project, Number RC13772-R1: "Safety evaluation for the performance to gaseous releases calculation from research reactor system ventilation" (1). The research contract has been successfully conducted involving the reactor operator and maintenance personnel of Kartini Reactor. Some of calculations for re-design of Kartini Reactor ventilation system has been done as well as the follow up of the re-design result, i.e., modification of ventilation system.

The research activities cover data acquisition of population, ecological variable, mathematical modeling of gas releases dissipating from the reactor building, ventilation system evaluation, and the source term analysis 
which is based on Kartini Reactor Design Base Accident. As well as in refer to the Safety Analysis Report (SAR), the Postulated Initiating Events (PIE), and other safety related documents ${ }^{(2)}$. 
Gaseous releases evaluation and safety performance improvement of Kartini Research Reactor Ventilation system (Syarip, Edy Triono, BS., Widyatmaka Susyanta, Hadi Kusuma)

\section{METHODOLOGY}

The method used for evaluating gaseous release covers the theoretical overview, data collecting, and experiments or measurements. The research activities are as follows:

1. Collecting data of Kartini reactor components and system for risk analysis, especially related to the ventilation systems up to emergency preparedness system;

2. Evaluation on retrofitting of ventilation system

3. Performance test of retrofitted ventilation system

4. Source term calculation using ORIGEN-2;

5. Activation of $\mathrm{Ar}^{41}$ and $\mathrm{Ni}^{16}$ calculation;

6. Referred to SAR and PIE documents

7. Experimental methods coverings:

Overview of the whole Kartini reactor data as a preparation for risk analysis calculation propagated from source term analysis following a Design Bases Accident (DBA) of Kartini Reactor ${ }^{(2,9)}$.

Assessment of meteorological data including Pasquil stability and the present population distribution around reactor from $1-5 \mathrm{~km}$ radius ${ }^{(2,8,10)}$.

Calculation and direct measurement of radioactive emission rate from stack and effective height of stack due to meteorology parameters, such as wind velocity, direction, temperature.

\section{Description of Kartini Reactor Ventilation System ${ }^{(2)}$}

Kartini Reactor ventilation system comprises blower unit, filter, ducting and stack. The main purpose of reactor ventilation system is to circulate the air in order to get fresh and clean air and to prevent the accumulation of contaminated air in the reactor building. The reactor building volume is $4.419 \mathrm{~m}^{3}$. The ventilation system is also intended to maintain the temperature in the reactor building at a constant operation temperature as well as to prevent temperature increase and heat accumulation. The air exchange frequency in the reactor building is maintained 6 times per hour, with the air outflow rate $396.3 \mathrm{~m}^{3} /$ minute. The air flow through ventilation holes is designed to be distributed equally through every part of containment, via primary outlet containing pre filter and absolute filter, before it goes to blower and to the $31.75 \mathrm{~m}$ height of reactor's stack. Control room ventilation system as a part of reactor ventilation system is installed to control the air circulation inflow and oufflow from the control room.

The ducting is constructed from rectangular plates where the intersections are connected by bolt flanges. The ducting ends at the channel under the stack. The primary channel is installed at the height of $9 \mathrm{~m}$. The ducting is divided into two branches up to the end of the channel at the height of $0.25 \mathrm{~m}$. Two units of blower which run alternately are installed as redundant system. Blower I and blower II are equipped with interlock systems. Two blowers are used for air absorption and compression into the stack. To adjust the amount of the airflow, a damper is installed at the inlet side and the outlet side of each blower. Filter housing is equipped with a manometer to monitor the dirt of air filter based on pressure distinction between air flows before and after entering the filter building.

When the reactor is in operation condition, some $\mathrm{Ar}^{41}$ is assumed to release due to the $\mathrm{Ar}^{41}$ gas content of the air that dissolves in water. When it is activated by neutrons then it becomes an active $\mathrm{Ar}^{41}$ gas, which can escape to the reactor room. The reactor core, which is submerged by water during reactor operation, becomes $\mathrm{Ar}^{41}$ gas producer where this gas will travel from the core to the reactor room. The gas type of radioactive waste is treated directly by filtration using pre-filter "Farr HEPA Filter", and absolute filter called: "Farr Hi flow Filter" for filtration of gas which contains particles size of $1-15 \mu \mathrm{m}$.

The dirty air removed from the reactor through gas stack, is passed through a filter system. The filter system consists of a pre-filter and an absolute filter of VILAIR brand. The purpose of the combination of two prefilters of P15/500 and PA/500 types is to hold the dirt/dust entering the ducting. The combination will absorb dust up to $10 \mu \mathrm{m}$ in diameter. It is assumed that $85 \%$ of the dust can be absorbed by this pre-filter. This type of filter, P15/500, can be cleaned by washing it using only plain water, at a washing power of 15-20 times. Air filter of 
PA/500 type is able to hold refined dust up to less than $1 \mu \mathrm{m}$ in diameter. Since this filter cannot be rewashed then it should be disposed after once usage.

Since the environmental safety requirements for contamination are very strict, in a sense that the permitted amount of radioactive dust or gas going out of the reactor room is very low, then an absolute filter is installed. The filter chosen is $N$ type of LUWA, where this type can hold back molecules of up to less than $0.3 \mu \mathrm{m}$ in diameter. The total dust that can be filtered is up to about $99.99 \%$. The pre-filter and the absolute filter are installed in such that they can be easily replaced and removed for maintenance. The air filter system can hold up molecules to less than $0.3 \mu \mathrm{m}$ in diameter, but $\mathrm{Ar}^{41}$ and $\mathrm{N}^{16}$ can still pass through it. It is therefore necessary to provide a stack of $31.75 \mathrm{~m}$ high in order to reduce the concentration of the air contamination to make the reactor operation reach the environmental safety requirements.

\section{RESULTS AND DISCUSSION}

The PIE was overviewed and it comprises 8 events, 3 of which are: the failure of transfer cask, loss of coolant water, and the failure of scram system causing radioactive releases to environment. The influence on atmosphere stability, temperature, rainfall, humidity, air pressure and velocity, and other factors such as population density, age, sex ratio of population and total population, was evaluated to determine the suitability of reactor. Atmosphere stability uses Pasquil-Gillford equation, which has six stability classes from extremely stable A to moderately stable $F$, is calculated to determine effective stack height $H$, and ground level concentration $X(x, y)^{(3,4)}$. Data of Kartini reactor component and system such as fuel elements, core, cooling water, building, ventilation, environmental variables and emergency preparedness have been acquired.

The environment monitoring at reactor site from January 2007 up to December 2008, shows that the rainfall in Kartini reactor site is $6.21 \mathrm{~mm}$, air pressure around reactor site is 1 atmosphere, humidity is $78.44 \%$, and daily temperature average is $26.36{ }^{\circ} \mathrm{C}$. The average maximum temperature is $31.43{ }^{\circ} \mathrm{C}$, while minimum temperature is $22.82^{\circ} \mathrm{C}$, during 2 years data. The wind direction is presented in Figure 1 for 2007 and Figure 2 for 2008 . All of the figures show wind directions tend to point $240^{\circ}$ direction. For wind velocity, Figure 3 , and 4 show similar with the previous data and time.

Verification of ventilation system components to assure which components should be modified and replaced-caused by ageing, has been conducted. The components such as rolling door, fan wheel housing and motor blower, air duct from reactor building to blower housing, have been improved. Comparison between formerly existing ventilation system and modified ventilation system is shown in Table 1, and the picture is shown in Figure 5. It is shown that modified system give a higher air pressure at the inlet and outlet air filter than before modification, whiles, air pressure different between inside reactor building and outside air is the same. This indicates that the new filter system is working more effective. The retrofitting of the blower system gives more space in the filter and fan wheel housing, and makes a maintenance program easy. Duct retrofitting decreases the air leakage possibility in the ventilation system.

The source term calculation using ORIGEN-2 has been done to estimate the ultimate goal of gaseous release to the environment, and the result is shown in Table 2. The source term analysis showed that the fission product accumulated in the reactor core at the start of operation was $4.838 \times 10^{6} \mathrm{Ci}$, it became $3.614 \times 10^{8} \mathrm{Ci}$ after 5 hours operation (time period of daily operation), and after reactor shut-down of 24 hours decay the fission product became $4.727 \times 10^{6} \mathrm{Ci}$. The activation product in the reactor coolant i.e. $\mathrm{Ar}^{41}$ and $\mathrm{Ni}^{16}$ was calculated and the calculation results show that $\mathrm{N}^{16}$ activity inside the reactor building is $4.1 \times 10^{-10} \mu \mathrm{Ci} / \mathrm{cm}^{3}$ and the $\mathrm{Ar}^{41}$ escaping to the atmosphere is $5.7 \times 10^{-12} \mathrm{mCi} / \mathrm{cm}^{3}$, which is lower than limit value for radiation worker of $2 \times 10^{-6}$ $\mu \mathrm{Ci} / \mathrm{cm}^{3}$.

Ground level concentration and effective stack height is calculated using Equation A-1 and A-2 (see Appendix A), and the plume of gas releases calculated using data of March 2007, March 2008 and March 2009 are shown in Figure 6, Figure 7, and Figure 8. Direct observation on the upper stack show that the radiation exposure is $2.33 \times 10^{-9}$ rad per second, exit velocity of gas from stack is 8 meters per second, absolute temperature effluent of gas is $26,2^{\circ} \mathrm{C}$, and outlet diameter of stack, $d=1$ meter and actual stack height 31.75 meters. 
Gaseous releases evaluation and safety performance improvement of Kartini Research Reactor Ventilation system (Syarip, Edy Triono, BS., Widyatmaka Susyanta, Hadi Kusuma)

For example, using March 2009 data, the value of ground level concentration on $x$ and $y$ coordinates, $x(x, y)$, is shown in Appendix A, with variable distance $x=100$ meters to 5,000 meters, while ordinate of $y$ is taken from 32 meters and 50 meters, the effective height of stack is obtained 38.55 meters. Initially the value of $x(x, y)$ for $x=100$ meters and $y=32$, and 50 meters shows $9.726 \times 10^{-19} \mathrm{rad} / \mathrm{m}^{3}$, rise up to $6.303 \times 10^{-14} \mathrm{rad} / \mathrm{m}^{3}$.and tends to decrease $1.598 \times 10^{-15} \mathrm{rad} / \mathrm{m}^{3}$ at distance 5,000 meters. Table- 3 shows some values of emission rate $Q$ from stack (rad/s) measured directly, the average value is used to calculate ground level concentration, $x(x, y)$. The above values are acceptable according to safety requirements ${ }^{(5)}$. The radioactive release or gas effluent from reactor stack was measured by gamma spectrometry, and the result shown that the radioactive element was detected as $\mathrm{K}^{40}$ (as natural radioactivity). The above calculated and measured values were far below the limit value determined by the regulatory body i.e. $6 \times 10^{-7} \mu \mathrm{Ci} / \mathrm{cm}^{3(6,7,8)}$. While the measurement result of airborne radioactivity in the reactor stack by using HI-Volume Air Sampler shows the average gross beta radioactivity is $6.15 \times 10^{-8} \mathrm{~Bq} / \mathrm{cm}^{3}$, this value is far below the limiting value stated in SAR of Kartini reactor i.e. $4 \times 10^{-5} \mathrm{~Bq} / \mathrm{cm}^{3}$ ${ }^{(2)}$, and conform with the requirements for research reactor in general ${ }^{(11,12)}$.

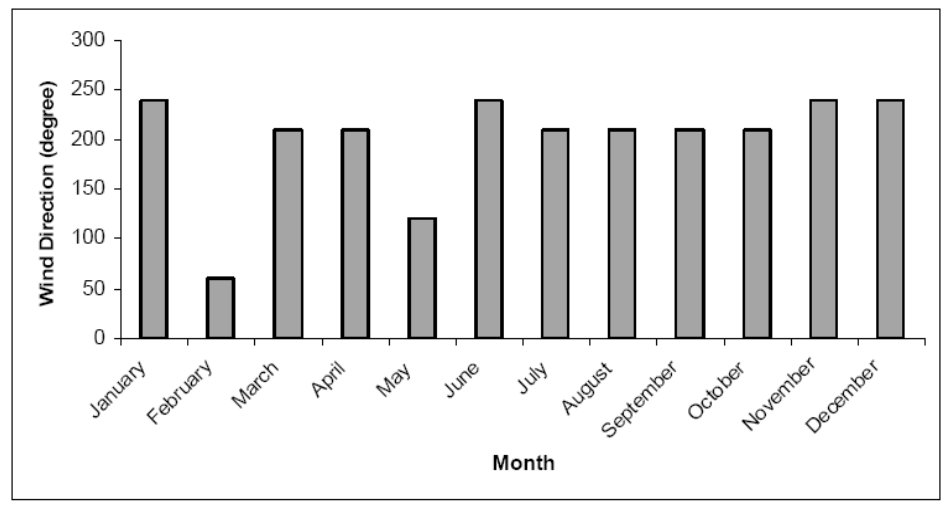

Figure 1. Wind direction at reactor site in 2007

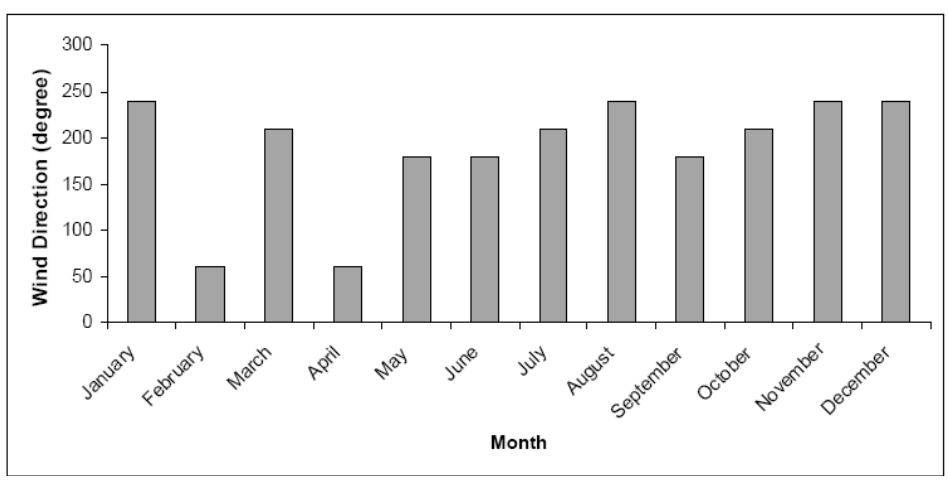

Figure 2. Wind direction at reactor site in 2008 


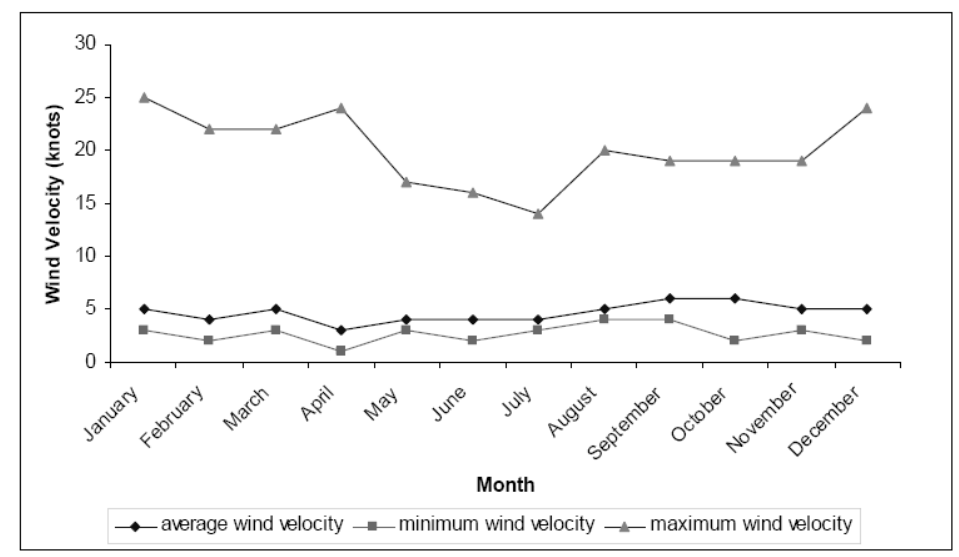

Figure 3. Wind velocity at reactor site in 2007

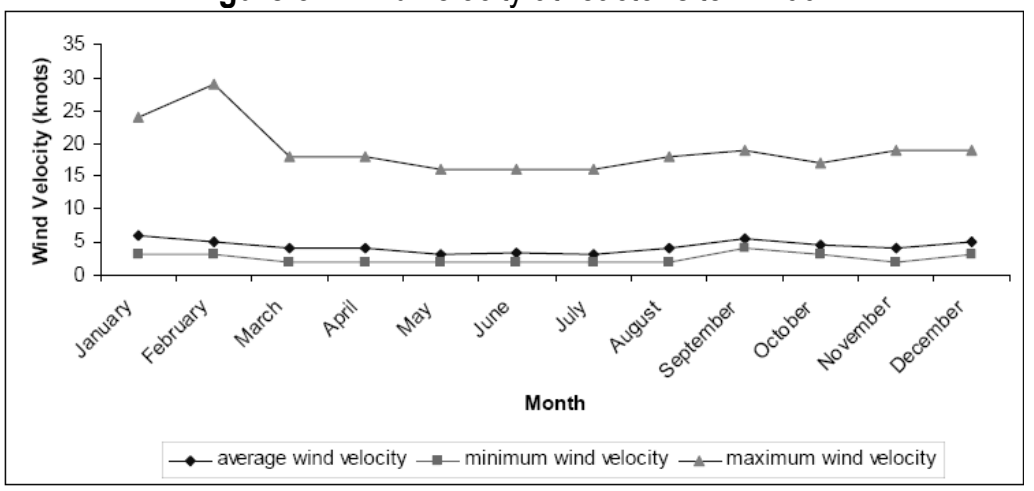

Figure 4. Wind velocity at reactor site in 2008

Table 1. Technical Specification of the Ventilation System before and after Retrofitting

\begin{tabular}{|c|c|c|c|}
\hline \multirow{2}{*}{ No } & \multirow{2}{*}{ Component's name } & \multicolumn{2}{|c|}{ Technical Specification } \\
\hline & & before & after \\
\hline 1 & Blower unit \& capacity & 2 units, each $40 \mathrm{~kW}$ & 2 units, each $30 \mathrm{~kW}$ \\
\hline 2 & Blower motor type & $\begin{array}{l}3 \text { phases, } 50 \mathrm{~Hz} \\
\operatorname{Cos} \varphi=0.85\end{array}$ & $\begin{array}{l}\text { MEZ, } 3 \text { phases } f=50 \mathrm{~Hz} \\
\operatorname{Cos} \varphi=0.80\end{array}$ \\
\hline 3 & Damper & Available & Available \\
\hline 4 & Fan wheel dimension & $\varnothing=1.22 \mathrm{~m}, \mathrm{~h}=0.61 \mathrm{~m}$ & $\varnothing=1.2 \mathrm{~m}, \mathrm{~h}=1.2 \mathrm{~m}$ \\
\hline 5 & Pulley dimension & $\varnothing 1=0.4 \mathrm{~m}, \varnothing 2=0.62 \mathrm{~m}$ & $\varnothing 1=0.26 \mathrm{~m}, \varnothing 2=0.34 \mathrm{~m}$ \\
\hline 6 & V-belt dimension & Length $=4.829 \mathrm{~m}$ & Length $=2.06 \mathrm{~m}$ \\
\hline 7 & $\begin{array}{l}\text { Air pressure, IN and OUT- } \\
\text { filter }\end{array}$ & $\begin{array}{l}\text { IN- filter }=0.16 \text { inch } \mathrm{H}_{2} \mathrm{O} \\
\text { OUT-filter }=0.7 \text { inch } \mathrm{H}_{2} \mathrm{O}\end{array}$ & 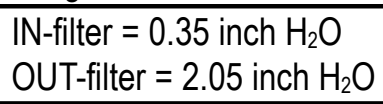 \\
\hline 8 & Type of air filter & HEPA, LUWA type $\mathrm{N}$ & HEPA, LUWA type N \\
\hline 9 & Room volume & $4.450 \mathrm{~m}^{3}$ & $4.418 \mathrm{~m}^{3}$ \\
\hline 10 & Ducting dimension & $1.693 \mathrm{~m}^{2}$ & $1.693 \mathrm{~m}^{2}$ \\
\hline 11 & Charcoal filter & Available & available \\
\hline 12 & $\begin{array}{l}\text { Air pressure difference } \\
\text { reactor building }\end{array}$ & $\Delta \mathrm{p} \leq 0.2 \mathrm{~cm} \mathrm{H}_{2} \mathrm{O}$ & $\Delta p \leq 0.2 \mathrm{~cm} \mathrm{H}_{2} \mathrm{O}$ \\
\hline
\end{tabular}

Table 2. Fission product activity of irradiated fuel elements calculated using ORIGEN-2 
Gaseous releases evaluation and safety performance improvement of Kartini Research Reactor Ventilation system (Syarip, Edy Triono, BS., Widyatmaka Susyanta, Hadi Kusuma)

\begin{tabular}{|c|l|c|c|}
\hline No & \multicolumn{1}{|c|}{ Legend } & $\begin{array}{c}\text { Total fission product radioactivities } \\
\text { (Ci/fuel rod) }\end{array}$ & $\begin{array}{c}\text { Radioactivities } \\
\text { (Ci/core) }\end{array}$ \\
\hline 1 & Start operation & $7.011 \times 10^{04}$ & $4.838 \times 10^{06}$ \\
\hline 2 & After 5 hours operation & $5.238 \times 10^{06}$ & $3.614 \times 10^{08}$ \\
\hline 3 & 3 hours decay & $4.561 \times 10^{05}$ & $3.147 \times 10^{07}$ \\
\hline 4 & 6 hours decay & $2.444 \times 10^{05}$ & $1.686 \times 10^{07}$ \\
\hline 5 & 9 hours decay & $1.593 \times 10^{05}$ & $1.099 \times 10^{07}$ \\
\hline 6 & 12 hours decay & $1.172 \times 10^{05}$ & $8.087 \times 10^{06}$ \\
\hline 7 & 15 hours decay & $9.495 \times 10^{04}$ & $6.552 \times 10^{06}$ \\
\hline 8 & 18 hours decay & $8.213 \times 10^{04}$ & $5.667 \times 10^{06}$ \\
\hline 9 & 21 hours decay & $7.413 \times 10^{04}$ & $5.115 \times 10^{06}$ \\
\hline 10 & 24 hours decay & $6.850 \times 10^{04}$ & $4.727 \times 10^{06}$ \\
\hline
\end{tabular}

Table 3. The value of emission rate from reactor stack, $Q$

\begin{tabular}{|c|c|}
\hline No. & $\begin{array}{c}\text { Emission rate (rad } \\
\text { per second) }\end{array}$ \\
\hline 1 & $2.33 \times 10^{-09}$ \\
\hline 2 & $2.29 \times 10^{-09}$ \\
\hline 3 & $2.26 \times 10^{-09}$ \\
\hline 4 & $2.40 \times 10^{-09}$ \\
\hline 5 & $2.38 \times 10^{-09}$ \\
\hline
\end{tabular}

\begin{tabular}{|c|c|}
\hline No. & $\begin{array}{c}\text { Emission rate (rad } \\
\text { per second) }\end{array}$ \\
\hline 6 & $2.33 \times 10^{-09}$ \\
\hline 7 & $2.29 \times 10^{-09}$ \\
\hline 8 & $2.27 \times 10^{-09}$ \\
\hline 9 & $2.30 \times 10^{-09}$ \\
\hline 10 & $2.26 \times 10^{-09}$ \\
\hline
\end{tabular}

\begin{tabular}{|c|c|}
\hline No. & $\begin{array}{c}\text { Emission rate (rad } \\
\text { per second) }\end{array}$ \\
\hline \hline 11 & $2.35 \times 10^{-09}$ \\
\hline 12 & $2.35 \times 10^{-09}$ \\
\hline 13 & $2.44 \times 10^{-09}$ \\
\hline
\end{tabular}

Average: $2.33 \times 10^{-09}$

\begin{tabular}{|c|l|c|c|}
\hline No & \multicolumn{1}{|c|}{ Name } & Before & After \\
\hline 1 & Rolling door & & \\
\hline 2 & $\begin{array}{l}\text { Fan wheel housing and motor } \\
\text { blower }\end{array}$ & & \\
\hline 3 & $\begin{array}{l}\text { Air duct from reactor building to } \\
\text { blower housing }\end{array}$ & \\
\hline
\end{tabular}




\begin{tabular}{|c|l|c|c|}
\hline No & Name & Before & After \\
\hline \hline 4 & Fan wheel housing & & \\
& & &
\end{tabular}

Figure 5: Comparison of Kartini reactor ventilation systems before and after improvements

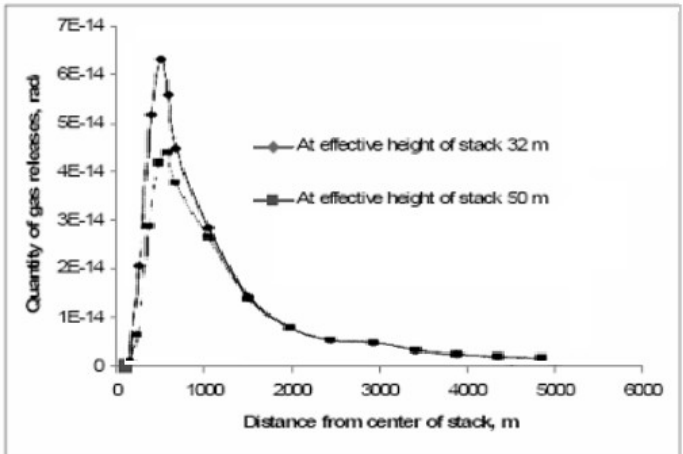

Figure 6. Plume in March 2007

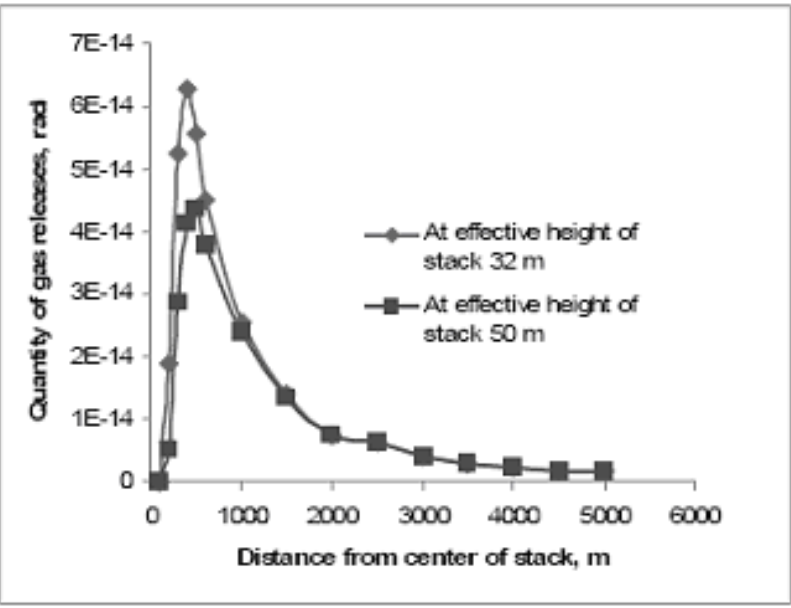

Figure 7. Plume in March 2008

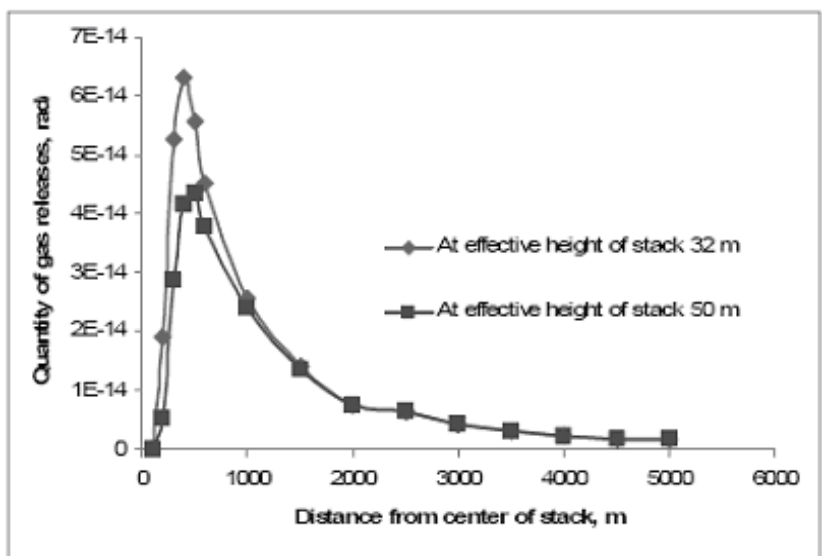


Gaseous releases evaluation and safety performance improvement of Kartini Research Reactor Ventilation system (Syarip, Edy Triono, BS., Widyatmaka Susyanta, Hadi Kusuma)

Figure 8. Plume in March 2009

While, a survey on the demography and population conditions surrounding the Kartini reactor site was done for $2003-2008$ period. The projected population of the survey area shows that the total population in 2008 within $5 \mathrm{~km}$ radius was 660,191 people. While in 2003 the total population in the same area was 637,352 people. The population growth rate of the survey area is about $1.04 \%$ and relatively stable.

\section{CONCLUSIONS}

From the above evaluation and the source term analysis can be drawn the conclusion that the fission product accumulated in the reactor core at the start of operation was $4.838 \times 10^{6} \mathrm{Ci}$, after of 5 hours operation it became $3.614 \times 10^{8} \mathrm{Ci}$, and after 24 hours decay, the fission product became $4.727 \times 10^{6} \mathrm{Ci}$. The $\mathrm{N}^{16}$ activity inside the reactor building is $4.1 \times 10^{-10} \mu \mathrm{Ci} / \mathrm{cm}^{3}$ and the $\mathrm{Ar}^{41}$ escaping to the atmosphere is $5.7 \times 10^{-12} \mathrm{mCi} / \mathrm{cm}^{3}$, which is lower than limit value for radiation worker of $2 \times 10^{-6} \mu \mathrm{Ci} / \mathrm{cm}^{3}$. A sample case by using March 2009 data, the value of ground level concentration on variable distance $x=100 \mathrm{~m}$ to $5,000 \mathrm{~m}$, was $9.726 \times 10^{-19} \mathrm{rad} / \mathrm{m}^{3}$, rise up to $6.303 \times 10^{-14} \mathrm{rad} / \mathrm{m}^{3}$ and tends to decrease to $1.598 \times 10^{-15} \mathrm{rad} / \mathrm{m}^{3}$ at distance $5,000 \mathrm{~m}$. Whiles the direct observation on the upper reactor stack show that the radiation exposure is $2.33 \times 10^{-9} \mathrm{rad} / \mathrm{s}$, exit velocity of gas from stack is $8 \mathrm{~m} / \mathrm{s}$, absolute temperature effluent of gas is $26.2^{\circ} \mathrm{C}$, and outlet diameter of stack, $\mathrm{d}=1 \mathrm{~m}$ and actual stack height $31.75 \mathrm{~m}$. Based on safety limit criteria from national regulation, the values of radiation exposure, ground level concentration combined with atmosphere stability and demography factor was very safe for the actual condition of Kartini reactor site. Therefore, the emergency preparedness program stated that if there is an accident, the evacuation is only for workers.

\section{REFERENCES}

1. CENTER FOR REACTOR TECHNOLOGY AND NUCLEAR SAFETY, BATAN, PROGRESS REPORT IAEA RC-13772-R1, "Safety Evaluation for the Performance to Gaseous Releases Calculation from Research Reactor System Ventilation", June (2009)

2. KARTINI REACTOR SAFETY ANALYSIS REPORT Rev. 7, Yogyakarta (2007)

3. INTERNATIONAL ATOMIC ENERGY AGENCY, "Source Term Derivation and Radiological Consequences Analysis of Research Reactor Accidents", IAEA TECDOC, Vienna, draft May (2005)

4. INTERNATIONAL ATOMIC ENERGY AGENCY, "Generic Models for Use in Assessing the Impact of Discharges of Radioactive Substances to the Environment", Safety Reports Series No. 19, IAEA, Vienna (2001)

5. INTERNATIONAL ATOMIC ENERGY AGENCY, "Safety of Research Reactors Safety Requirements", Safety Standards Series NS-R-4, IAEA, Vienna (2005)

6. BAPETEN, Baku Tingkat Radioaktivitas Lingkungan, SK Kepala BAPETEN No. 02/Ka-Bapeten/VI 1999.

7. BAPETEN, Ketentuan Keselamatan Kerja terhadap Radiasi, Lampiran SK Kepala BAPETEN No. 01/KaBAPETEN/V-1999.

8. BAPETEN, Evaluasi Tapak Reaktor Daya Untuk Aspek Penentuan Dispersi Zat Radioaktif di Udara dan Air, dan Pertimbangan Distribusi Penduduk di Sekitar Tapak Reaktor Daya, PERKA BAPETEN No. 3, Tahun (2008).

9. SYARIP, et al., "Root Cause Analysis of Swelling Problem in Kartini Reactor", Proceedings of an International Conference: Safe Management and Effective Utilization, IAEA-CN-156, STI/PUB/1360, ISBN 978-92-0160108-7, ISSN 1991-2374, @ IAEA, Vienna (2008).

10. BEYCHOK, R. MILTON (2005). Fundamentals Of Stack Gas Dispersion (4th Edition ed.). author-published, ISBN 0-9644588-0-2. OCLC (Online computer Library Center), (2005).

11. N. SADEGHI, et al., "Radioactive Dispersion Model for Tehran Research Reactor and Radioisotope Laboratory", Proceedings of International Conference on Environmental Engineering and Applications (ICEEA), ISBN: 978-1-4244-8619-9, Singapore, (2010). 
12. BENT LAURITZE, et al., "Atmospheric Dispersion of Radioactive Releases from a Nuclear Research Reactor: Measurement and Modeling of Plume", Geometry and Gamma Radiation Field, Proceedings of $8^{\text {th }}$ Int. Conf. on Harmonization within Atmospheric Dispersion Modeling for Regulatory Purposes, (2003).

\section{APPENDIX A}

In this model, the contaminant is assumed to be normally distributed around the central axis of the plume, and that atmospheric stability and wind speed determine the atmospheric dispersion characteristics of the contaminant in the downwind direction. This model is described by the Pasquill-Gifford equation:

$$
\chi(\mathrm{x}, \mathrm{y})=\frac{\mathrm{Q}}{\pi \sigma_{\mathrm{y}} \sigma_{\mathrm{z}} \mu} \exp \left[-\frac{1}{2}\left(\frac{\mathrm{y}^{2}}{\sigma_{\mathrm{y}}^{2}}+\frac{\mathrm{H}^{2}}{\sigma_{\mathrm{z}}^{2}}\right)\right]
$$

where, $x(x, y)=$ ground level concentration in rad per cubic meter at point $x, y$.

$x \quad=$ downwind distance on plume center line, $\mathrm{m}$

$y \quad=$ cross-wind distance, $m$

$Q \quad=$ emission rate, $\mathrm{rad} / \mathrm{s}$

$\sigma_{y}, \sigma_{z}=$ horizontal \& vertical standard deviation of contaminant concentration in the plume, $m$

$\mu \quad=$ mean wind speed at level of plume center line, meters per second

$H \quad=$ effective stack height, meters

If the effluent gas has a significant exit velocity, or if it is at high temperature, it will rise to a level higher than the stack. The effective stack height, therefore, is the sum of the actual stack height, plus a factor that accounts for the exit velocity and the temperature of the effluent gas:

$$
\mathrm{H}=\mathrm{h}+\mathrm{d}\left(\frac{\mathrm{v}}{\mu}\right)^{1.4}\left(1+\frac{\Delta \mathrm{T}}{\mathrm{T}}\right)
$$

where: $h$ = actual stack height, meters

$d$ = stack outlet diameter, meters

$v$ = exit velocity of gas, meters per second

$\mu=$ mean wind speed, meters per second

$\Delta T=$ difference between ambient and effluent gas temperatures

$T$ = absolute temperature of effluent gas

The calculation of ground level concentration using Pasquil-Gifford modeling atmospheric stability for sample data of March 2009 is shown in Table A, below:

Table A. Calculation Result of Ground Level concentration

\begin{tabular}{|c|c|c|c|c|c|}
\hline$x(\mathrm{~m})$ & $y(\mathrm{~m})$ & $\sigma_{y}(\mathrm{~m})$ & $\sigma_{z}(\mathrm{~m})$ & $H$ & $x\left(\mathrm{Rad} / \mathrm{m}^{3}\right)$ \\
\hline \hline 100 & 32 & 12 & 8 & 38.548198 & $9.726 \times 10^{-19}$ \\
\hline 100 & 50 & 12 & 8 & 38.548198 & $5.784 \times 10^{-21}$ \\
\hline 200 & 32 & 24 & 16 & 38.548198 & $1.894 \times 10^{-14}$ \\
\hline 200 & 50 & 24 & 16 & 38.548198 & $5.261 \times 10^{-15}$ \\
\hline 300 & 32 & 35 & 22 & 38.548198 & $5.252 \times 10^{-14}$ \\
\hline 300 & 50 & 35 & 22 & 38.548198 & $2.875 \times 10^{-14}$ \\
\hline 400 & 32 & 42 & 28 & 38.548198 & $6.303 \times 10^{-14}$ \\
\hline 400 & 50 & 42 & 28 & 38.548198 & $4.148 \times 10^{-14}$ \\
\hline 500 & 32 & 55 & 36 & 38.548198 & $5.568 \times 10^{-14}$ \\
\hline
\end{tabular}


Gaseous releases evaluation and safety performance improvement of Kartini Research Reactor Ventilation system (Syarip, Edy Triono, BS., Widyatmaka Susyanta, Hadi Kusuma)

\begin{tabular}{|l|l|l|l|l|l|}
\hline 500 & 50 & 55 & 36 & 38.548198 & $4.363 \times 10^{-14}$ \\
\hline 600 & 32 & 65 & 42 & 38.548198 & $4.511 \times 10^{-14}$ \\
\hline 600 & 50 & 65 & 42 & 38.548198 & $3.788 \times 10^{-14}$ \\
\hline 1000 & 32 & 105 & 65 & 38.548198 & $2.558 \times 10^{-14}$ \\
\hline 1000 & 50 & 105 & 65 & 38.548198 & $2.392 \times 10^{-14}$ \\
\hline 1500 & 32 & 150 & 90 & 38.548198 & $1.399 \times 10^{-14}$ \\
\hline 1500 & 50 & 150 & 90 & 38.548198 & $1.354 \times 10^{-14}$ \\
\hline 2000 & 32 & 200 & 125 & 38.548198 & $7.545 \times 10^{-15}$ \\
\hline 2000 & 50 & 200 & 125 & 38.548198 & $7.407 \times 10^{-15}$ \\
\hline 3000 & 32 & 300 & 175 & 38.548198 & $4.031 \times 10^{-15}$ \\
\hline 3000 & 50 & 300 & 175 & 38.548198 & $3.998 \times 10^{-15}$ \\
\hline 4000 & 32 & 400 & 220 & 38.548198 & $2.235 \times 10^{-15}$ \\
\hline 4000 & 50 & 400 & 220 & 38.548198 & $2.225 \times 10^{-15}$ \\
\hline 5000 & 32 & 480 & 250 & 38.548198 & $1.603 \times 10^{-15}$ \\
\hline 5000 & 50 & 480 & 250 & 38.548198 & $1.598 \times 10^{-15}$ \\
\hline
\end{tabular}

